\title{
A novel naproxen derivative capable of displaying anti-cancer and anti-migratory properties against human breast cancer cells
}

\author{
Jolly Deb ${ }^{1 *}$, Joydeb Majumder ${ }^{2}$, Sankar Bhattacharyya ${ }^{3}$ and Siddhartha Sankar Jana ${ }^{\text {** }}$
}

\begin{abstract}
Background: Increasingly, the role of chronic inflammation and its mediators in tumor generation and progression is gaining importance in the field of cancer research. In this context, candidature of non steroidal anti-inflammatory drugs (NSAIDs) as potential anti-tumor therapeutic agent is being evaluated globally. In the present study we have evaluated the anti-cancer effect of a series of newly synthesized naproxen derivatives on human breast cancer cell lines.

Methods: MCF-7 (poorly invasive) and MDA-MB-231 (highly invasive) cells were treated with different concentrations of naproxen sodium and its derivatives in vitro, and the underlying mechanism of action was monitored by employing studies related to induction of apoptosis, activation of caspases, cell-cycle progression, synthesis of $\mathrm{PGE}_{2}$ and cellular migration.

Results: After a preliminary screening using MCF-7 and MDA-MB-231 cells, it was evident that naproxen derivative 4 has a better killing property compared to its parent compound naproxen sodium (NS). On further investigation, it was apparent that the observed growth inhibitory activity on MDA-MB-231 cells after treatment with 4 , was not due to cell cycle arrest but due to an early induction of apoptosis and subsequent induction of caspases 3 and 9. Derivative 4 could also inhibit COX activity in MDA-MB-231 cells as evidenced by reduction in prostaglandin E2 secretion. Moreover, 4 was capable of delaying the overall migration rate of MDA-MB-231 cells in vitro.

Conclusion: In this study we report that a naproxen-derivative (4) has powerful anti-inflammatory and anti-tumor properties as it induces appreciable amount of apoptosis in breast cancer cell line, and can also delay migration of cancer cells (MDA-MB-231) which would in turn delay cancer cell invasion and formation of secondary tumours in primary breast cancer patients. Thus, we propose that 4 is worthy of further investigation due to its potential as a therapeutic agent in anti-tumor treatment regimen.
\end{abstract}

Keywords: MCF-7, MDA-MB-231, MTT assay, Apoptosis, Inflammation, Metastasis

\section{Background}

The functional relationship between inflammation and cancer was first brought into picture in 1863, when Rudolf Virchow hypothesized that cancer originates at the site of chronic inflammation [1]. Since then a vast number of studies have emphasized on the role of chronic inflammation in tumorogenesis [2] and potential use of nonsteroidal anti-inflammatory drugs (NSAID) as anti-cancer

\footnotetext{
* Correspondence: bcjd@iacs.res.in; bcssj@iacs.res.in

'Department of Biological Chemistry, Indian Association for the Cultivation of Science, 2A \& 2B Raja S. C. Mullick Road, 700032 Kolkata, India

Full list of author information is available at the end of the article
}

agents [3-5]. Although gastrointestinal bleeding and increased cardiovascular $(\mathrm{CV})$ problems are associated with most of the known NSAIDs, naproxen is known for its fewer CV effects with a possible cardioprotective role in human [6]. In a phase II clinical trial, naproxen was found to be safe and effective in treating progressive prostate cancer with early recurrent disease [7] and a recent study using a murine model of induced colon cancer, has also indicated the anti-cancer properties of this drug [8].

The molecular mechanisms, by which NSAIDs impart their chemopreventive effects, are a matter of intense debate till date. The most accepted hypothesis has focused 
on their property to reduce the levels of prostaglandins by cyclooxygenase (COX-1 and -2 ) inhibition [9]. Over expression of COX-2 [10] along with increased levels of prostaglandin $\mathrm{E}_{2}\left(\mathrm{PGE}_{2}\right)$ in breast cancer patients have been reported [11]. It is of note that $\mathrm{PGE}_{2}$, a known COX2-derived prostaglandin, plays a significant role in progression and metastasis of cancer cells by modulating local tumor microenvironment [12]. Hence, molecules with an enhanced capacity to reduce $\mathrm{PGE}_{2}$ in cancer cells are of great interest.

To demonstrate the above hypothesis we chose to work with four naproxen-derivatives [13] 1-4 (Figure 1). In the present study we report that naproxen derivative 4 can be employed as an anti-cancer agent due to its enhanced cytotoxic activity against human breast cancer cell lines and also address the underlying mechanism of action by employing studies related to induction of apoptosis, activation of caspases, cell-cycle progression, synthesis of $\mathrm{PGE}_{2}$ and cellular migration.

\section{Methods}

Synthesis of naproxen derivatives (1-4)

All the naproxen derivatives were synthesized according to the methods described in our previously published literature [13].

\section{Cell culture}

The human breast cancer cell line MCF-7 and the mouse macrophage RAW 264.7 cells were cultured in high glucose Dulbecco's minimal essential medium (DMEM) supplemented with 10\% FBS (Life Technologies) and 1\%<smiles>COc1ccc2cc(C(C)C(=O)O)ccc2c1</smiles>

Figure 1 Naproxen and its derivatives (1-4).
L-glutamine-penicillin-streptomycin (Life Technologies) and Insulin (in case of MCF-7), and maintained in a humidified incubator at $37^{\circ} \mathrm{C}$ and $5 \% \mathrm{CO}_{2}$. MDA-MB-231, a rather aggressive form of human breast cancer cell line, was grown in Leibovitz's L-15 medium in presence of $10 \%$ fetal bovine serum and antibiotics, penicillin and streptomycin and required a $37^{\circ} \mathrm{C}$ incubator with $100 \%$ air environment for optimum growth. They grew as a monolayer in the culture plate and were regularly passaged at $~ 80 \%$ confluency.

Cell lines were purchased from ATCC (American Type Culture Collection, Manassas, VA, USA) and maintained in our cell culture facility.

\section{MTT assay}

Briefly, $10^{4}$ cells/well were seeded in a 96-well plate and left to adhere overnight. Compounds were prepared as a stock (50 mM) in DMSO-media, prior to addition to the cells. The culture medium was replaced with medium containing the compounds at various concentrations (1 $\mathrm{mM}, 3 \mathrm{mM}, 5 \mathrm{mM}, 10 \mathrm{mM}$ ) and incubated for another $24 \mathrm{~h}$ following addition of $100 \mu \mathrm{l}$ of 3-(4,5Dimethylthiazol-2-yl)-2,5-diphenyltetrazolium bromide (MTT; $1 \mathrm{mg} / \mathrm{ml}$ ) stain per well, incubated for $3 \mathrm{~h}$ at $37^{\circ} \mathrm{C}$ and subjected to DMSO (150 $\mu \mathrm{l} /$ well). Incubation was carried out further for another $10 \mathrm{~min}$ at $37^{\circ} \mathrm{C}$, and the absorbance was recorded at $570 \mathrm{~nm}$ using a plate reader (VARIOSKAN, ThermoFisher).

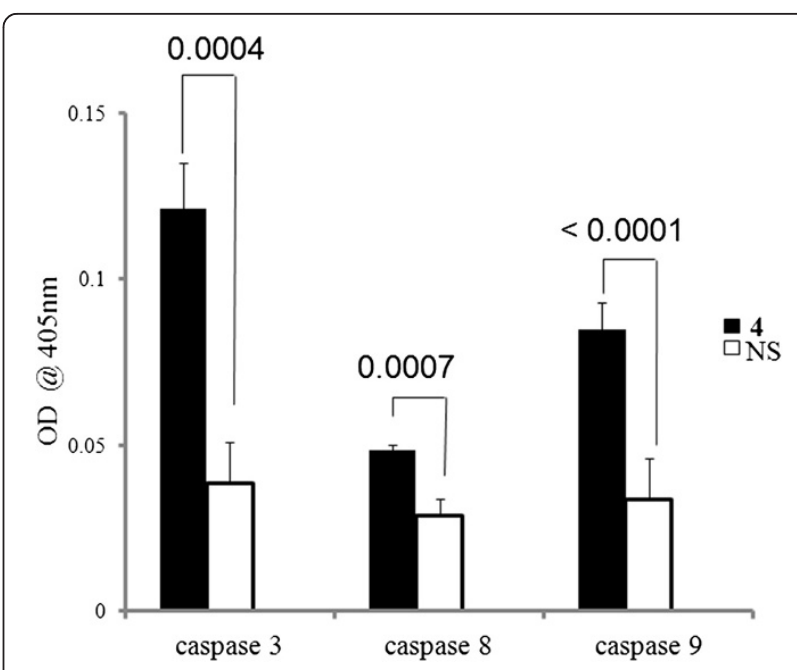

Figure 2 Derivative 4 induces caspase 3/9 activation. MDA-MB-231 cells were left untreated or treated with NS and $\mathbf{4}$ for 6 h, and cell lysates were prepared. The lysates were then incubated with substrates of caspase 8, 9 and 3, and OD value at $405 \mathrm{~nm}$ was measured using a standard plate reader. Treatment with $\mathbf{4}$ resulted in a significant increase in the activation of caspase -9 and -3 compared to its parent compound NS. Each point on the graph represents Mean \pm SD; $p$ values of $t$-test are indicated on top of horizontal bars. $n=3$. 


\section{Apoptosis assay}

Following treatment of cells $\left(1.5 \times 10^{6}\right.$ MDA-MB-231 cells/well in a 12-well plate) with naproxen sodium or $\mathbf{4}$ for two different time points, apoptosis was determined by "Apo-TRACE Apoptotic Cell Staining Kit" (\# CS1110; Sigma), as per manufacturer's instruction. Control cells were treated with DMSO-media. In principle, viable cells are Apo-TRACE $/ \mathrm{PI}^{-}$, dead or necrotic cells are ApoTRACE ${ }^{-} / \mathrm{PI}^{+}$, early apoptotic cells are Apo-TRACE ${ }^{+} / \mathrm{PI}^{-}$, and late apoptotic cells are Apo-TRACE $/ \mathrm{PI}^{+}$.

\section{Caspase assay}

To detect the levels of caspases-3, -8 and -9 in cell lysates from treated and untreated cells $\left(1.5 \times 10^{6}\right.$ MDA-MB-231 cells/well in a 6-well plate), Caspase Colorimetric Protease Assay Sampler Kit (\# KHZ1001; Life Technologies) was used as per manufacturer's protocol. In principle, active caspase 3, 8 or 9 cleaves the individual fluorogenic substrate to release the fluorochrome, which can be detected using a microtiter plate reader at $405 \mathrm{~nm}$.

\section{Cell cycle study}

In order to determine the cell cycle phase distribution of nuclear DNA, cells $\left(1.5 \times 10^{6} \mathrm{MDA}-\mathrm{MB}-231\right.$ cells/well in a 6 -well plate) were harvested and fixed in $100 \%$ chilled methanol and permeabilized. Cells were treated with RNase (10 $\mu$ from $2 \mathrm{mg} / \mathrm{ml}$ stock) and nuclear DNA was labeled with PI $(125 \mu \mathrm{g} / \mathrm{ml})$. Cell-cycle phase distribution was determined on a FACSCalibur using CellQuest software [14]. For each sample, 10,000 events were acquired for analysis after excluding cell doublets and clumps by gating. Histogram display of FL2-A ( $\mathrm{x}$ axis, PIfluorescence) versus counts ( $\mathrm{y}$ axis) has been displayed in Figure 2 .

\section{$\mathrm{PGE}_{2}$ synthesis assay}

The amount of secreted $\mathrm{PGE}_{2}$, from treated and untreated cell $\left(1.5 \times 10^{6}\right.$ MDA-MB-231 cells/well in a 12-well plate) culture supernatants, was determined using Prostaglandin E2 EIA kit (Cayman Chemicals, Ann Arbor, MI). The conditioned medium was centrifuged to remove any cells and
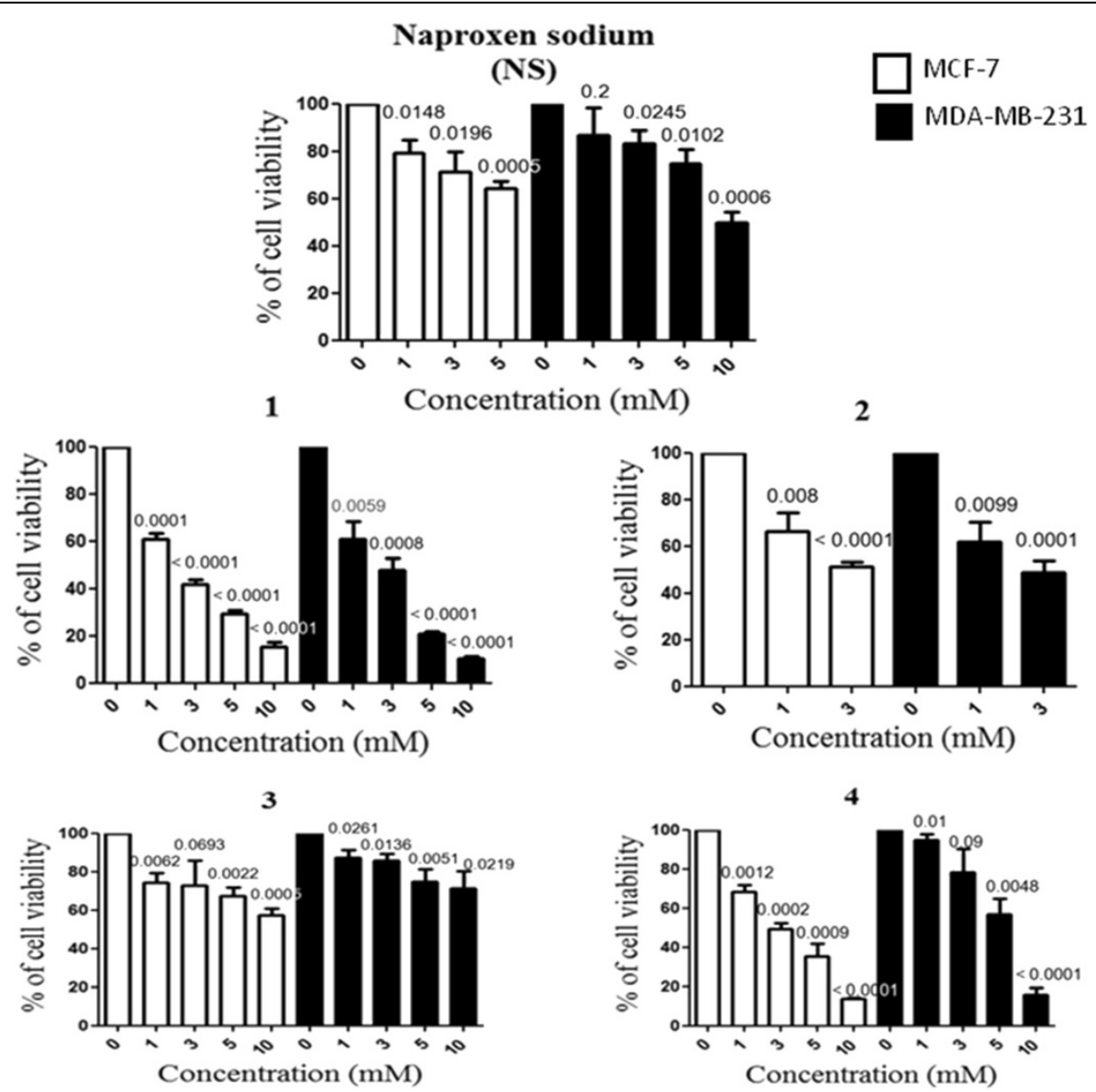

Figure 3 Naproxen-derivatives induce cytotoxic killing in two breast cancer cell lines. MCF-7 and MDA-MB-231 cells were treated with different concentrations of naproxen sodium (NS) and its derivatives for $24 \mathrm{~h}$ followed by addition of MTT. Except 3, rest of the derivatives showed an enhanced killing effect on both the cell lines, when compared with NS. Each point on the graph represents Mean \pm SD. $n=3$. 
Table 1 In vitro cytotoxicity of naproxen sodium and its derivatives

\begin{tabular}{lcl}
\hline & $\mathbf{2 4 - h}$ IC $\mathbf{5 0}, \mathbf{m M}$ & \\
\hline Compound & MCF-7 & MDA-MB-231 \\
& ER $^{+}, \mathbf{P R}^{+}$ & ER $^{-}, \mathbf{P R}^{-}, \mathbf{H E R}^{2} / \mathbf{N e u}^{-}$ \\
\hline Naproxen sodium (NS) & $>5$ & $\sim 10$ \\
1 & $\sim 1.8$ & $\sim 1.6$ \\
2 & $\sim 3$ & $\sim 3$ \\
3 & $>10$ & $>10$ \\
4 & $\sim 2.7$ & $\sim 5.9$ \\
\hline
\end{tabular}

stored immediately at $-70^{\circ} \mathrm{C}$ until assay. The assay was done according to the manufacturer's protocol.

\section{Cell migration assay}

MDA-MB-231 cells were grown to confluency in a $9 \mathrm{~cm}^{2}$ culture plate. A $200 \mu \mathrm{l}$ sterile pipette tip was used to introduce a scratch followed by treatment with different concentrations (1 $\mathrm{mM}$ and $3 \mathrm{mM}$ ) of naproxen sodium, 4 or DMSO. Still and/or video images were captured during or after $22 \mathrm{~h}$ to monitor wound closure rate to measure migration speed and polarity [15].

\section{Statistical analysis}

$\mathrm{IC}_{50}$ was calculated by nonlinear regression analysis using OriginPro. The mean and SD values were computed using Microsoft Excel, and GraphPad software was used to calculate $\mathrm{p}$ values.

\section{Results and discussion}

Enhanced cytotoxic killing is evident by naproxen-derivatives against MCF-7 and MDA-MB-231 cells

The cytotoxic effect of the synthesized molecules, the naproxen-derivatives (Figure 1), was first examined in a preliminary screening using two human breast cancer cell lines, MCF-7 and MDA-MB-231 cells (Figure 3) and the overall findings have been summarized in Table 1. Based on their $\mathrm{IC}_{50}$ values, except 3 , rest of the derivatives were found to have a better killing property compared to their parent compound naproxen sodium (NS). It is of note that although $\mathbf{1}$ and $\mathbf{2}$ could exhibit better killing properties $\left(\mathrm{IC}_{50} \sim 2 \mathrm{mM}\right.$ and $\sim 3 \mathrm{mM}$, respectively) against the cancer cell lines, they also proved to be cytotoxic against the mouse macrophage cell line RAW 264.7 [13]. Because macrophages serve as the first line of defense during tumor establishment [16], a drug molecule with little to no toxic effect against macrophages would be advantageous. Keeping these in mind, we
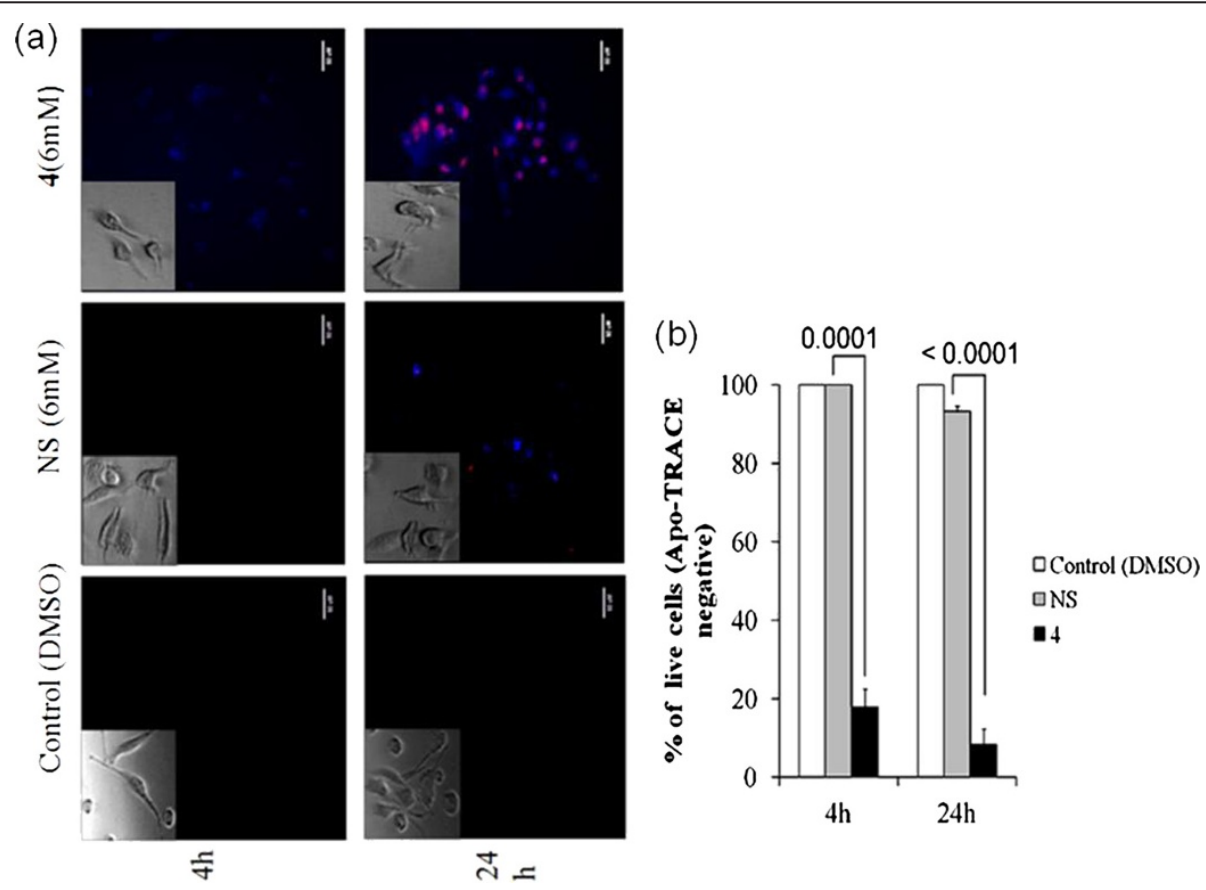

Figure 4 Derivative 4 can induce apoptosis in MDA-MB-231 cells. MDA-MB-231 cells were incubated with or without cytotoxic compounds for $4 \mathrm{~h}$ and $24 \mathrm{~h}$, and were stained with the Apo-TRACE cell staining kit followed by fluorescence imaging studies. (a) Cells treated with $\mathbf{4}$ lead to an early induction of apoptosis than NS. (Inset showing bright field image of control and drug treated MDA-MB-231 cells indicating morphological changes in cell structure upon drug treatment.) At least 3 microscopic fields were examined for staining and representative images are shown here. (b) Bar graph representing percentage of live cells. Each point on the graph represents Mean \pm SD. $n=3$. 
conclude that $\mathbf{4}$ has a better cytotoxic effect against the two cancer cell lines employed in the study with minimal adverse effect on RAW 264.7 cell.

\section{Treatment with 4 induces early apoptosis in MDA-MB-231} cells

Because MDA-MB-231 is a highly aggressive cell line compared to MCF-7, we sought to study our compound of interest in depth using the former one. In order to understand whether the observed cell killing was due to apoptosis or necrosis, we looked for Apo-Trace positive cells in drug-treated samples. We could detect early apoptotic cells within the first $4 \mathrm{~h}$ of $4(6 \mathrm{mM})$ treatment and late apoptotic cells at a later time point $(24 \mathrm{~h})$. Cells treated with NS at the same concentration could not undergo apoptosis by $4 \mathrm{~h}$ and very few apoptotic cells were evident at $24 \mathrm{~h}$ time point (Figure 4).

\section{Naproxen derivative 4 induces caspase-3/9 mediated apoptosis in MDA-MB-231 cells}

Many researchers have commented on the crucial role of caspase-cascade system in apoptosis, and the role of

(a)
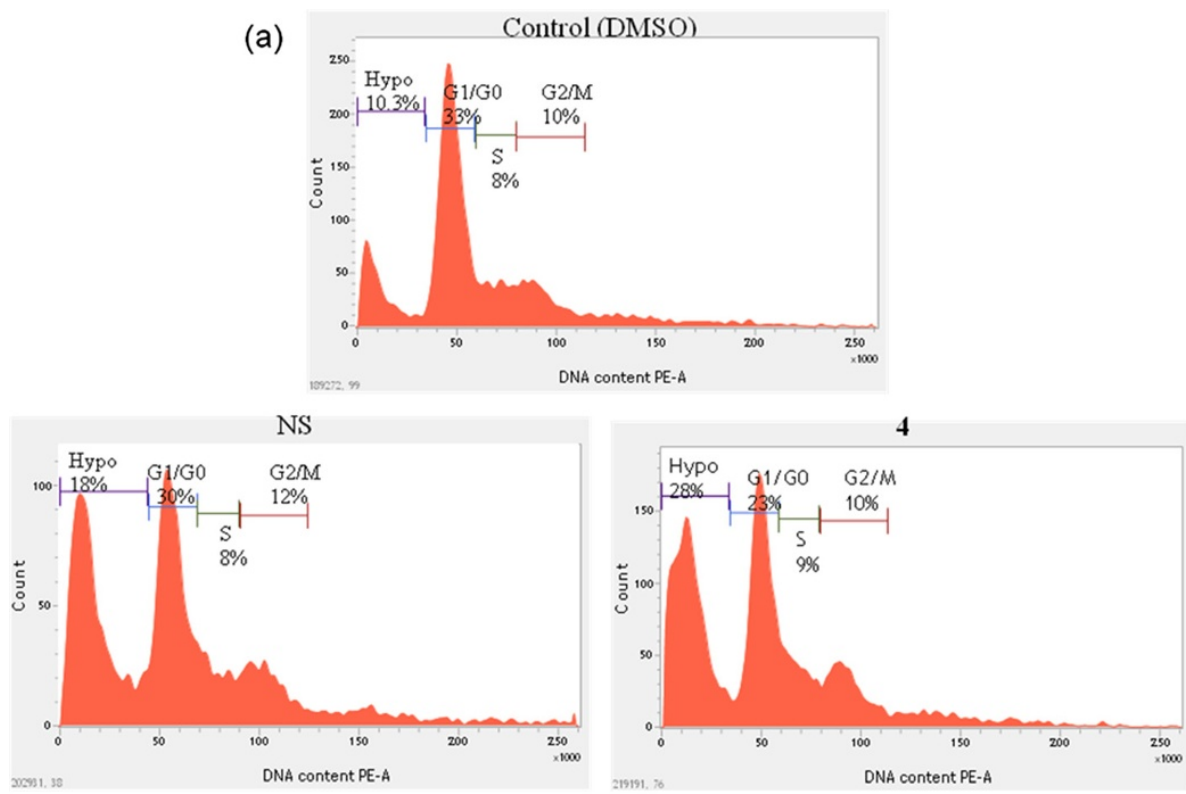

(b)

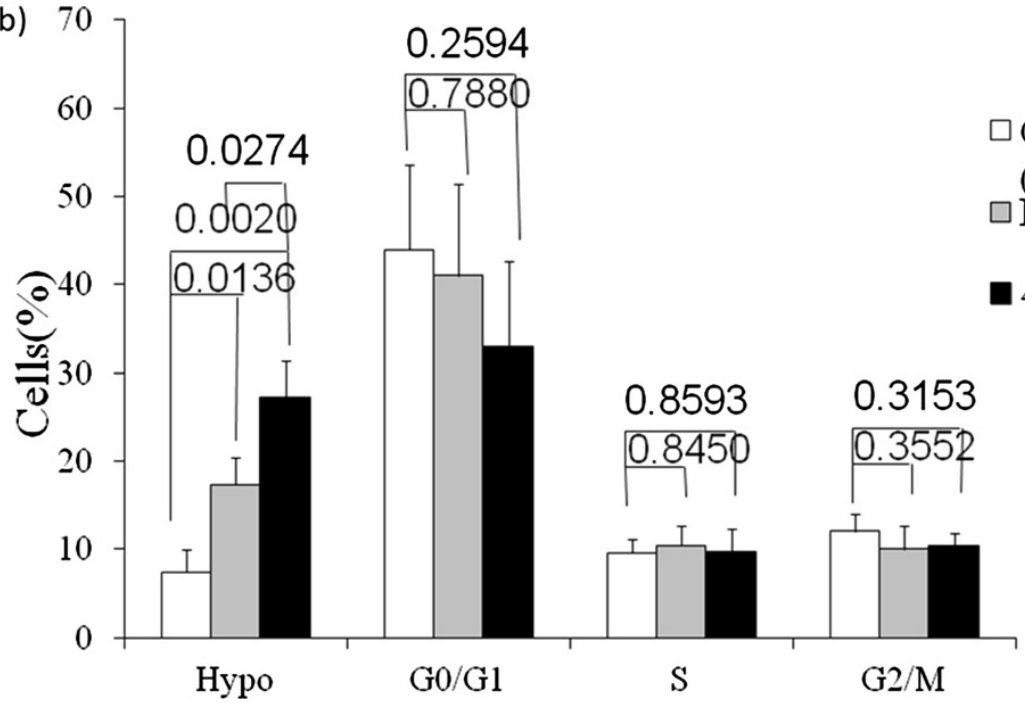

Figure 5 Cell cycle arrest in MDA-MB-231 cells is not evident upon treatment with 4. MDA-MB-231 cells were treated with DMSO or cytotoxic compounds for $24 \mathrm{~h}$. Followed by fixation and permeabilization, the cells were stained with PI. (a) Cell-cycle phase distribution was determined by flow cytometric analysis. (b) No significant cell-cycle arrest in cells treated with either NS or $\mathbf{4}$ was detected. Each point on the graph represents Mean $\pm S D, p$ values of $t$-test are indicated on top of horizontal bars, $n=3$. 
caspase- $8,-9$ as executioner and -3 as death protease [17] is well accepted. Treatment with $4(6 \mathrm{mM})$ for $6 \mathrm{~h}$ resulted in a significant increase in the activation of caspase -9 and -3 compared to its parent compound NS (Figure 2). These results suggest that the $\mathbf{4}$ mediated observed apoptosis in MDA-MB-231 cells is due to activation of caspases-3 and -9 . Hence, our study clearly indicates involvement of the intrinsic pathway [18] of caspase activity in inducing apoptosis in MDA-MB-231 cells.

Neither NS nor 4 induces cell-cycle arrest in MDA-MB-231 cells

Growing bodies of evidence suggest that molecules, capable of affecting cell cycle progression in cancer cells, can enhance sensitivity of cancer cells towards anti-cancer drugs $[19,20]$. As our study could clearly indicate an increase in apoptotic cell death after treatment with 4, we carried out cell-cycle analysis to detect any changes in cell-cycle progression (Figure 5). We failed to notice significant cell-cycle arrest in cells treated with NS or 4 for $24 \mathrm{~h}$ compared to DMSO treated control cells. However, in drug-treated samples, we could detect a high percentage of cell population residing in the hypoploid state, indicating apoptotic cell population. Hence, both NS and its derivative 4 mediated observed growth inhibitory activity on MDA-MB-231 cells was not due to cell cycle arrest but due to induction of apoptosis.

Naproxen derivative 4 inhibits $\mathrm{PGE}_{2}$ synthesis in MDA-MB-231 cells

A hallmark of breast cancer cells is up-regulated COX-2, which in turn result in an increase in $\mathrm{PGE}_{2}$ synthesis [21]. As NSAIDs are known to affect COX-2 activity and reduce $\mathrm{COX}-2$ induced $\mathrm{PGE}_{2}$ synthesis, we wanted to determine if $\mathbf{4}$ could also act in the similar fashion. We checked the level of $\mathrm{PGE}_{2}$ in conditioned cell culture medium collected from MDA-MB-231 cells after DMSO or drug-treatment for $24 \mathrm{~h}$. At $6 \mathrm{mM}$ concentration, 4 could significantly reduce $\mathrm{PGE}_{2}$ secretion by MDA-MB231 cells compared to NS (Figure 6), confirming 4 to be a more potent inhibitor of COX-2 mediated $\mathrm{PGE}_{2}$ production. The observed phenomenon could be due to inhibition of COX-2, as the parent compound Naproxen is a well known COX inhibitor. This finding might also establish $\mathbf{4}$ as a promising candidate in reducing inflammation which is known to play significant role in cancer progression [22].

\section{Treatment with 4 can slow-down cell-migration rate in} MDA-MB-231cells

After evaluating the effect of $\mathbf{4}$ in the production of $\mathrm{PGE}_{2}$, we wanted to test the influence of $\mathbf{4}$ on the cancer cell migration as it is now well established that $\mathrm{PGE}_{2}$

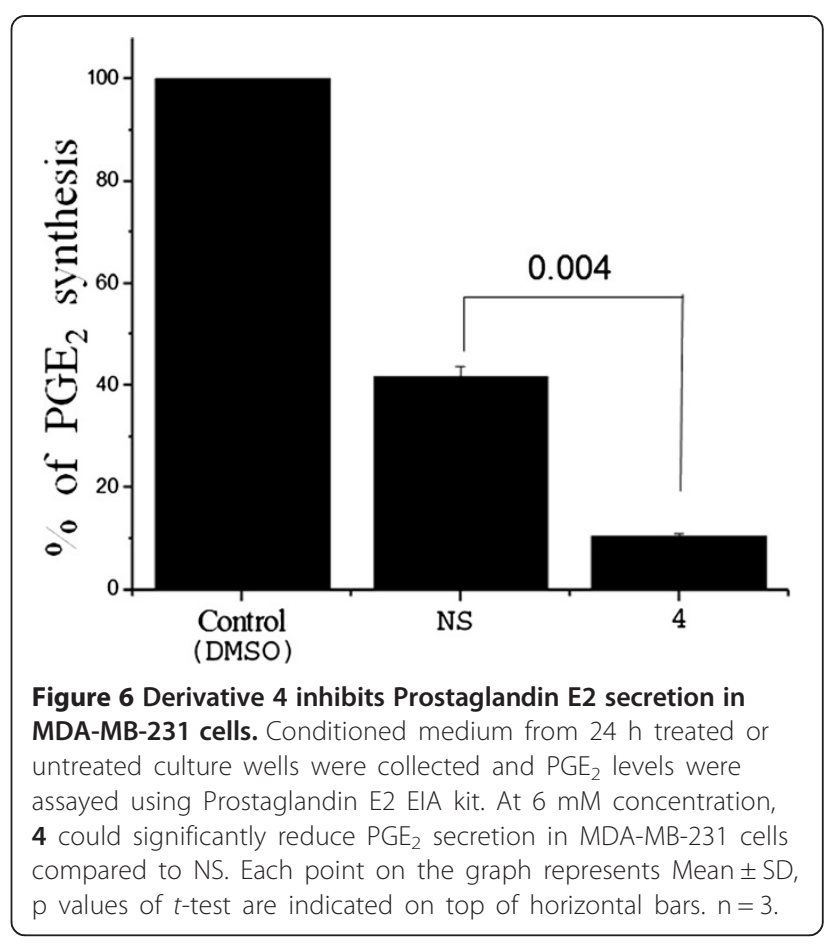

plays a vital role in the migration of breast cancer cells. Poor prognosis of breast cancer patients are associated with secondary tumor formation, thus, any compound that can intervene with migrational capacity and metastasis of breast cancer cells may have profound impact on improved survivability of such patients. We opt for MDAMB-231 over MCF-7 due to its highly metastatic and migratory properties compare to the non- metastatic and poorly migrating MCF-7 cells [21]. Cells treated with NS for $22 \mathrm{~h}$ at a higher concentration $(3 \mathrm{mM})$ covered $66 \%$ of the gap, whereas, 4 , at the same concentration and time point, could cover only $6 \%$ of the gap (Figure $7 \mathrm{a}$ ).

We then opted for a lower dose $(1 \mathrm{mM})$ of drug (NS and 4) to study dose-dependent migratory inhibition in the same cell line, and captured time-lapse video images of treated/untreated cells for duration of $22 \mathrm{~h}$ (Figure $7 \mathrm{~b}$ ). We, then, randomly selected seven time points to calculate the migration speed (Table 2) based on the distance travelled/h (Figure 7c). The cells, treated with NS, migrated at a speed of $8.5 \mu \mathrm{m} / \mathrm{h}$ whereas, treatment with 4 led to a much slower rate $(4.5 \mu \mathrm{m} / \mathrm{h})$ of migration; almost half of the migration speed of NS-treated cells. These results clearly indicate that 4 could successfully delay the migration of MDA-MB-231 cells, most probably by reducing COX-2 derived $\mathrm{PGE}_{2}$ synthesis. Since migration is the first step towards invasion and metastasis of cancer cells, 4 might as well interfere with the metastasis process. However, further experimentation using murine cancer-model would be essential to support the claim. 


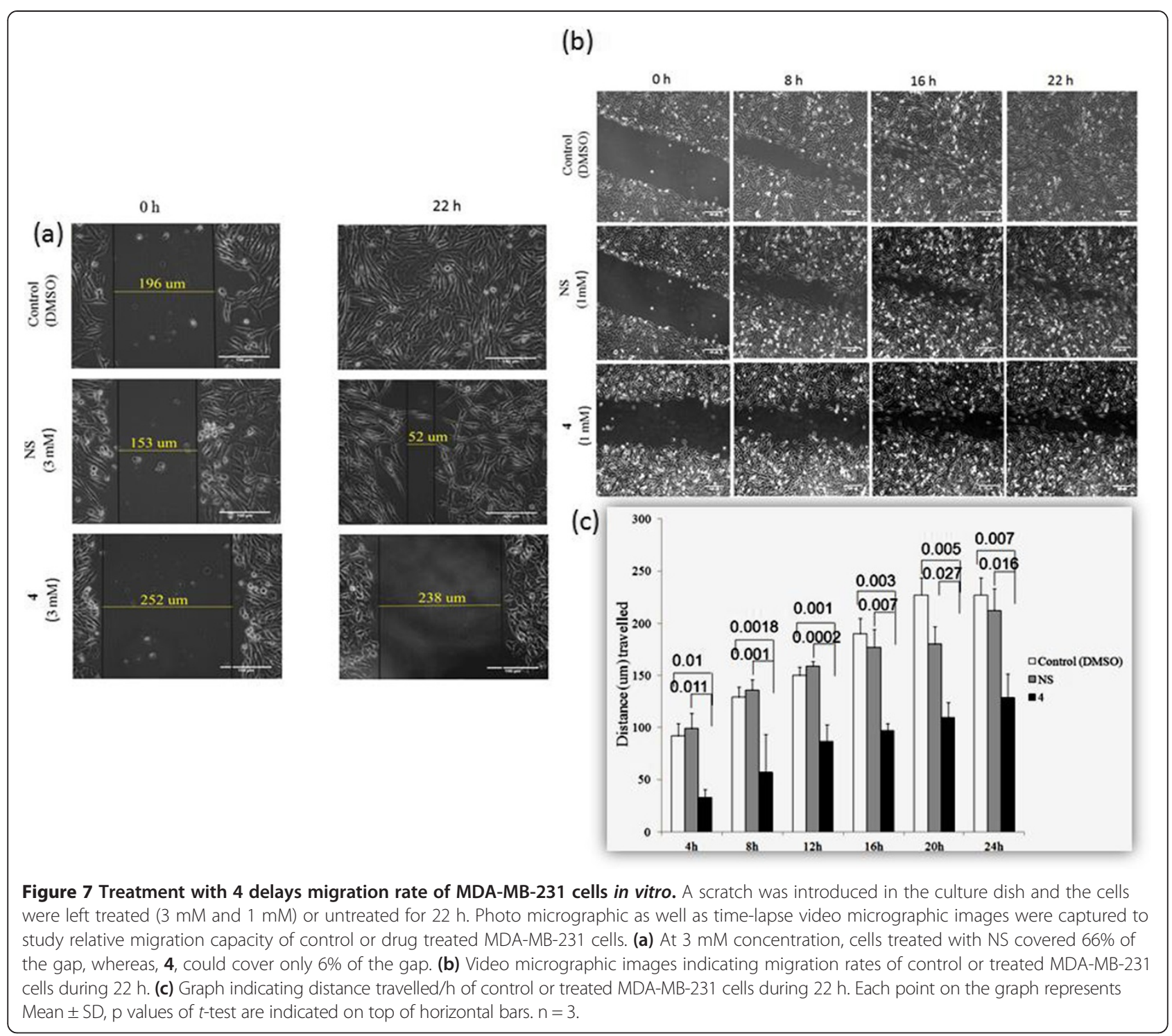

\section{Conclusions}

Here, we have presented a new peptide based derivative 4 obtained from the NSAID naproxen capable of showing cytotoxic property against two human breast cancer cell lines and, have also provided brief experimental evidence, supported by literature, to address the underlying mechanism of action. In summary our studies suggest that derivative $\mathbf{4}$ mediated cell-killing is due to an early induction of apoptotic event followed by activation of

Table 2 In vitro migration speed of control or treated MDA-MB-231 as determined by scratch wound assay

\begin{tabular}{ll}
\hline Drug Treatment $(\mathbf{1} \mathbf{~ m M})$ & Migration speed $(\boldsymbol{\mu m} / \mathbf{h})$ \\
\hline Control & $\sim 12$ \\
NS & $\sim 8.83$ \\
4 & $\sim 5.3$ \\
\hline
\end{tabular}

intrinsic caspase-cascade at a molecular level, while no sign of significant cell-cycle arrest was evident. Furthermore, we have showed that 4 can inhibit $\mathrm{PGE}_{2}$ synthesis and delay tumor cell migration (in vitro). Since the derivative $\mathbf{4}$ is capable of forming hydrogel at room temperature [13] it can also be employed as the hydrogel drug-delivery system [23] for sustained release of the anti-cancer agent. However, it is also important to note the difference in the $\mathrm{IC}_{50}$ vales of 4 against p53 wild type MCF-7 $(\sim 3 \mathrm{mM})$ and p53 null MDA-MB-231 ( 6 mM) cells. The highly skewed killing of MCF-7 cells by this compound might indicate the involvement of p53 mediated apoptotic pathway. One of the major off target effects of $\mathbf{4}$ may include p53 targets such as bax. Further experimentation is needed to elucidate these potential off target effects of this novel anticancer compound. Potential limitation of this drug could be the fact that it may include p53 as one of its targets, 
thus the dose needed to induce significant killing may be relatively elevated for p53 muted cancer cells compared to p53 wild type cancer cells. Overall these studies imply that peptide based naproxen-derivative $\mathbf{4}$ can serve as an anticancer agent.

\section{Competing interests}

The authors declare that they have no competing interests.

\section{Authors' contributions}

JD designed and conducted all the biological studies, JM synthesized the compounds, and SB performed and analyzed the FACS data. SSJ conceived the study, discussed in analyzing the data. JD and SB wrote the manuscript, and SSJ edited the manuscript. All the authors have read and approved the final manuscript.

\section{Acknowledgements}

SSJ thanks DBT for financial support (CEIB project BT/01/CEIB/N/13). JD thanks DBT, New Delhi for RA Fellowship. JM thanks CSIR, New Delhi for SRF (CSIR Grant No. 09/080(0776)/2011-EMR-1). We are also grateful to Prof. Parthasarathi Dastidar and his group members, Department of Organic Chemistry, IACS, Kolkata; Mahua Rani Das, Sumit Kr. Dey and other group members of Dr. S.S. Jana, IACS, Kolkata, for technical support.

\section{Author details}

'Department of Biological Chemistry, Indian Association for the Cultivation of Science, 2A \& 2B Raja S. C. Mullick Road, 700032 Kolkata, India. ${ }^{2}$ Department of Organic Chemistry, Indian Association for the Cultivation of Science, 2A \& 2B Raja S. C. Mullick Road, 700032 Kolkata, India. ${ }^{3}$ Department of Zoology, Sidho Kanho Birsha University, Purulia, India.

Received: 18 February 2014 Accepted: 30 July 2014

Published: 7 August 2014

\section{References}

1. Balkwill F, Mantovani A: Inflammation and cancer: back to Virchow? Lancet 2001, 357:539-45.

2. Shacter E, Weitzman SA: Chronic inflammation and cancer. Oncology 2002, 16:217-26.

3. Thun MJ, Henley SJ, Patrono C: Non-steroidal anti-inflammatory drugs as anticancer agents: mechanistic, pharmacologic, and clinical issues. J Natl Cancer Inst 2002, 94:252-66.

4. Baron JA, Sandler RS: Nonsteroidal anti-inflammatory drugs and cancer prevention. Annu Rev Med 2000, 51:511-23.

5. Garcia-Rodriguez LA, Huerta-Alvarez C: Reduced risk of colorectal cancer among long-term users of aspirin and nonaspirin nonsteroidal antiinflammatory drugs. Epidemiology 2001, 12:88-93.

6. Bombardier C, Laine L, Reicin A, Shapiro D, Burgos-Vargas R, Davis B, Day R, Ferraz MB, Hawkey CJ, Hochberg MC, Kvien TK, Schnitzer TJ: Comparison of upper gastrointestinal toxicity of rofecoxib and naproxen in patients with rheumatoid arthritis. VIGOR Study Group. N Engl J Med 2000, 343:1520-28.

7. Srinivas S, Feldman D: A Phase II trial of calcitriol and naproxen in recurrent prostate cancer. Anticancer Res 2009, 29:3605-10.

8. Suh N, Reddy BS, DeCastro A, Paul S, Lee HJ, Smolarek AK, So JY, Simi B, Wang CX, Janakiram NB, Steele V, Rao CV: Combination of atorvastatin with sulindac or naproxen profoundly inhibits colonic adenocarcinomas by suppressing the p65/b-catenin/cyclin D1 signaling pathway in rats. Cancer Prev Res 2011, 14:1895-902.

9. Williams CS, Mann M, DuBois RN: The role of cyclooxygenases in inflammation, cancer, and development. Oncogene 1999, 18:7908-16.

10. Ristimaki A, Sivula A, Lundin J, Lundin M, Salminen T, Haglund C: Prognostic significance of elevated cyclooxygenase-2 expression in breast cancer. Cancer Res 2002, 62:632-35.

11. Basu GD, Pathangey LB, Tinder TL, Gendler SJ, Mukherjee P: Mechanisms underlying the growth inhibitory effects of the cyclo-oxygenase-2 inhibitor celecoxib in human breast cancer cells. Breast Cancer Res 2005, 7:422-35.

12. Chen EP, Smyth EM: COX-2 and PGE 2 -dependent immunomodulation in breast cancer. Prostaglandins Other Lipid Mediat 2011, 96:14-20.
13. Majumder J, Das MR, Deb J, Jana SS, Dastidar P: $\beta$-Amino acid and amino- alcohol conjugation of a nonsteroidal anti-inflammatory drug (NSAID) imparts hydrogelation displaying remarkable biostability, biocompatibility, and anti- inflammatory properties. Langmuir 2013, 29:10254-63.

14. Bhattacharyya S, Deb J, Patra AK, Thuy Pham DA, Chen W, Vaeth M, Berberich-Siebelt F, Klein-Hessling S, Lamperti ED, Reifenberg K, Jellusova J, Schweizer A, Nitschke L, Leich E, Rosenwald A, Brunner C, Engelmann S, Bommhardt U, Avots A, Muller MR, Kondo E, Serfling E: NFATc1 affects mouse splenic $B$ cell function by controlling the calcineurin-NFAT signaling networ. J Exp Med 2011, 208:823-39.

15. Cory G: Scratch-wound assay. Methods Mol Biol 2011, 769:25-30.

16. Dunn GP, Old LJ, Schreiber RD: The three Es of cancer immunoediting. Annu Rev Immunol 2004, 22:329-60.

17. Mcllwain DR, Berger T, Mak TW: Caspase functions in cell death and disease. Cold Spring Harb Perspect Biol 2013, 5:a008656.

18. Hengartner MO: The biochemistry of apoptosis. Nature 2000, 407:770-76.

19. Waldman T, Zhang Y, Dillehay L, Y U J, Kinzler K, Vogelstein B, Williams J: Cell-cycle arrest versus cell death in cancer therapy. Nat Med 1997, 3:1034-36.

20. Ehrhardt H, Wachter F, Grunert M, Jeremias I: Cell cycle-arrested tumor cells exhibit increased sensitivity towards TRAIL-induced apoptosis. Cell Death Dis 2013, 4:e661.

21. Timoshenko AV, Xu G, Chakrabarti S, Lala PK, Chakraborty C: Role of prostaglandin E2 receptors in migration of murine and human breast cancer cells. Exp Cell Res 2003, 289:265-74.

22. Nakanishi M, Rosenberg DW: Multifaceted roles of $\mathrm{PGE}_{2}$ in inflammation and cancer. Semin Immunopathol 2013, 35:123-37.

23. Wang H, Yang Z: Molecular hydrogels of hydrophobic compounds: a novel self-delivery system for anti-cancer drugs. Soft Matter 2012, 8:2344-47.

doi:10.1186/1471-2407-14-567

Cite this article as: Deb et al:: A novel naproxen derivative capable of displaying anti-cancer and anti-migratory properties against human breast cancer cells. BMC Cancer 2014 14:567.

\section{Submit your next manuscript to BioMed Central and take full advantage of:}

- Convenient online submission

- Thorough peer review

- No space constraints or color figure charges

- Immediate publication on acceptance

- Inclusion in PubMed, CAS, Scopus and Google Scholar

- Research which is freely available for redistribution 